\title{
Virtuous Persons and Virtuous Actions in Business Ethics and Organizational Research
}

\author{
Miguel Alzola \\ Fordham University
}

\begin{abstract}
The language of virtue is gaining wider appreciation in the philosophical, psychological, and management literatures. Ethicists and social scientists aim to integrate normative and empirical approaches into a new "science of virtue." But, I submit, they are talking past each other; they hold radically different notions of what a virtue is. In this paper, I shall examine two conflicting conceptions of virtue, what I call the reductive and the non-reductive accounts of virtue. I shall critically study them and argue that the non-reductive view is the best philosophical account of virtue and the only one that can account for the way we talk about virtue in business and in everyday life. We can only understand what it means to act virtuously through the examination of the attitudes, beliefs, desires, and inclinations of the virtuous agent. I shall illustrate the differences between the reductive and non-reductive accounts by considering the virtue of gratitude.
\end{abstract}

KEY WORDS: virtue ethics, character strengths, positive psychology, positive organizational scholarship, gratitude

\section{INTRODUCTION}

$\mathrm{T}$ HERE IS A GROWING CONCERN with virtue and moral character in the philosophical, psychological, and management literatures (Annas, 2011; Doris, 2002; Snow, 2010; Goodwin, Piazza, \& Rozin, 2014; Wright \& Goodstein, 2007; Cameron, 2013). Philosophers, economists, psychologists, and management scholars aim to integrate parallel efforts in normative ethical theory and empirical research into a new "science of virtue" (Richardson, 2003; Narvaez, 2008; Van Slyke et.al, 2012; Bruni \& Sugden, 2013; Timpe \& Boyd, 2014). ${ }^{1}$ Yet, a number of ambiguities hinder the evolution of such an interdisciplinary program. One issue that demands greater conceptual clarity is the notion of virtue-and the related concept of character strengths.

In this paper, I shall examine two competing strategies to define virtue, which I shall call the reductive (or dispositional) account and the non-reductive account of virtue. After examining how the reductive account works, I shall discuss four decisive objections against it and defend the non-reductive account. I shall further argue that some virtues - i.e. gratitude - do not conform to the reductive approach because they cannot be reduced to dispositions to act in accordance with certain rules and principles. Rather, they are primarily the arena of inner states and processes, such as beliefs, emotions, desires, and attitudes. 
Two polemics are at stake here, namely, a philosophical polemic over the reduction of virtue to duty categories and a methodological polemic over the reduction of virtue to actions in empirical studies. Ultimately, this is a paper about two kinds of reduction. The first is concerned with the priority of aretaic or deontic concepts in the conceptualization of virtue. ${ }^{2}$ The second is about the role of character in the conceptualization of virtuous actions.

The expected contribution of this paper to the literature is threefold. First, it collects and digs through recent work by psychologists and management scholars, trying to uncover the notion of virtue they work with. This summary is of considerable interest for philosophers who want to know more about the relevant social science underlying the "science of virtue." Second, the paper reconstructs and refines work by philosophers on moral character, trying to uncover the notion of virtue they work with, which should be valuable to social scientists. Put together, these contributions will be valuable for the scholar who is trying to bring the literatures on virtue in psychology, management, and business ethics into conversation with each other. Third, this paper integrates the philosophical and methodological polemics mentioned above through the notion of rightness in virtue ethics. Roughly, we cannot reduce virtue to actions (the second polemic) if we truly acknowledge the role of character in the conceptualization of virtue (the first polemic) because a virtuous action is the action performed by a person of good character. We will understand what it means to act virtuously only through the study of the virtuous person rather than through observing the performance of his or her actions. ${ }^{3}$

This is a normative paper. I am building on philosophical theories of virtue, personality psychology, positive psychology, and positive organizational scholarship in order to examine the notion of virtue and the role of moral character in business ethics and management research with the purpose of contributing to further research on the interplay of the virtues with other mental states. Therefore, I do not aim to develop testable propositions or any empirical measures of virtue. This article is, to my knowledge, the first to uncover (and raise doubts) about social scientists' favored account of virtue - the reductive account - in the literature on virtue in business ethics, positive psychology, and organizational behavior.

The paper is organized as follows. In Section One, I describe the recent trend in virtue research in philosophy, psychology, and organizational scholarship. In Section Two, I examine the concepts of trait, character, and virtue attribution in connection with the is/ought distinction and the split between personality and character. In Section Three, I present two alternative conceptualizations of virtue. In Section Four, I press four objections to the reductive strategy. In Section Five, I defend a non-reductive account of the virtues. In Section Six, I apply the conceptual framework outlined in the previous sections to examine the virtue of gratitude. Section Seven concludes.

\section{BACK TO CHARACTER AND VIRTUE}

The emergence of contemporary virtue ethics has had an invigorating effect on mainstream moral theory. It also has had a stimulating impact on the social sciences. 
There is a longstanding interest in character and traits in psychology—particularly trait theory in personality psychology (Allport, 1937). This trend has been freshly revitalized by "positive psychology," a recent movement that is focused on the study of the strengths and virtues that enable individuals and communities to flourish (Peterson and Seligman, 2004). Organizational scholars have imported this concern from psychology; they aim to find the drivers of positive behavior in the workplace as a way of understanding, predicting, and explaining high performance (Cameron, Dutton, and Quinn, 2003). Similarly, business ethicists have emphasized the centrality of character and virtue concepts in business ethics (Solomon, 1997; Moberg, 1997, Hartman, 1998; Koehn, 1998; Moore, 2005). And economists are following suit (McCloskey, 2006; Bruni \& Sugden, 2013; Sugden, 2015).

\subsection{Character Strengths in the Social Sciences}

In this section I shall identify three milestones in the history of trait theory. The first can be traced back to ancient Greece, with Hippocrates suggesting the existence of four fundamental "personality types" or "bodily humors" (sanguine, melancholic, choleric, and phlegmatic) and Theophrastus - a disciple of Aristotle-portraying the characters of "common types" (the liar, the cheater, etc.) of his Greek society. The second is Darwin's emphasis on individual variation based on genetic differences, and Freud's and Jung's psychological theories, which set in motion an influential stream of work on traits and personality types. The third milestone is work by Gordon Allport, who is commonly credited as the founder of the trait approach.

Escaping both a psychoanalytic and a behaviorist approach, Allport thought that language has evolved to capture important aspects of personality. He postulated a common-sense approach to personality based on language, which he called a lexical hypothesis. Allport (1930) argued that although behavior is variable, there is also a constant portion of each person that corresponds to each person's unique, key qualities; such unique traits-rather than common traits-are the real units of personality. They exist within an individual and have status as psychophysical realities. In Allport's theory, traits are understood as personal dispositions. Individuals differ in terms of their goals, motives, and styles. He distinguishes cardinal, central, and secondary traits: cardinal dispositions exert a significant influence on behavior, central traits are general characteristics that can be found to some degree in every person, and secondary traits are those characteristics that are seen only under certain circumstances (Allport, 1937).

Psychologists are quick to highlight the distinction between traits and states. According to Cattell (1978), traits are relatively permanent dispositions whereas states are temporary conditions within an individual. Cattell's theory defines traits as units of personality that have predictive value; a trait is what defines what a person will do when faced with a given situation. Funder (1997) summarizes the three main features of trait theory as follows: (1) it is based on empirical research, (2) the ultimate criterion for any measurement of personality is whether it can be used to predict behavior, and (3) it focuses exclusively on individual differences.

The trait approach has been revived by contemporary "positive psychologists," who use the tools of scientific psychology to study what they call "character strengths." 
Like personality psychologists, positive psychologists advocate the study of character and virtue as "legitimate topics of psychological inquiry and informed societal discourse" (Peterson and Seligman, 2004: 3). Positive psychology is concerned with mental health, wellness, and well-being above and beyond the absence of disease, distress, and disorder. They focus on subjective experiences, positive traits, and institutions that enable positive experiences and positive traits (Seligman and Csikszentmihalyi, 2000). As opposed to traditional psychology—which focuses on human pathology and assumes that humans are inherently weak-positive psychology is primarily concerned with human strength and thriving.

The rehabilitation of the language of virtue in the social sciences by positive psychologists reinforces the importance of individual differences and suggests that such differences are stable and general, though changeable and shaped in the individual's environment (Kristjansson, 2013). Positive psychology aims to offer psychologists some tools to think, operationalize, and measure character traits, thereby making traits a legitimate topic of scientific research (Carr, 2011). It provides "strategies of measurement and explanatory power out of the realm and reach of philosophy" (Peterson and Seligman, 2004: 13). According to this new research program in the social sciences, individuals and their positive traits need to be accorded a central role in understanding the good life.

An offshoot of the positive psychology tradition, Positive Organizational Scholarship (POS) pursues the scientific study of positive outcomes, attributes, and processes in an organizational context. POS broadens positive psychology's focus by examining "thriving dynamics within organizations," and emphasizing "the role of embedded contexts in explaining successful dynamics and positive states of individuals, groups and organizations" (Dutton, Glynn, \& Spreitzer, 2006: 641). POS aims to offer an umbrella term that summarizes how, when, and why individuals achieve the good life in work contexts (Cameron \& Spreitzer, 2011). Building upon positive psychology, community psychology, and organizational development, POS is focused on "flourishing, positive dynamics, and the best of the human condition" as opposed to overcoming ills and solving problems (Cameron, Dutton, \& Quinn, 2003: 10).

\subsection{The Virtues in Normative (Business) Ethics}

Virtue ethics is one of the major normative theories in business ethics (Trevino \& Nelson, 2003; Donaldson and Werhane, 2007; Boatright, 2012; Velasquez, 2012). Like trait theory, the origins of virtue ethics can be traced back to the Greeks (Crisp, 1996; Sherman, 1997; Cooper, 1999; Annas, 2011). Virtue ethics is typically defined as an ethics of being, as opposed to its main rivals, which are better described as act-centered or rule-centered. It requires that we focus on being good as persons, thereby emphasizing the centrality of motives and passions in choice, the role of character in moral theorizing, and a concern for the whole course of a person's life (in contrast to competing approaches that emphasize rules of actions).

Virtue ethics is often distinguished from consequentialist and deontological theories by saying that it is an agent-based - rather than an action-based - moral theory that is concerned with the question of how to live (Slote, 1983). ${ }^{4}$ Under consequentialist moral theories, what is permitted, what is required, and what is obligatory will 
be determined by reference to whether the action brings about a higher utility than any other alternative action that the agent could perform. Under Kantian ethics, an action is permissible, obligatory, or prohibited depending on whether it respects (or fails to respect) someone's humanity and whether its maxim can be universalized. In contrast, virtue ethics holds that an action is permissible, required, or wrong if and only if it is an action that a person of good character would (or would not) characteristically perform under the circumstances. Thus, what is right and what is wrong in virtue ethics is defined by reference to agents and their traits, which are the basic moral concepts. Consequently, virtue ethics is a theory of role modeling; role models work not only as sources but also as teachers of ethical standards.

As in the social sciences, the appreciation of virtue has inspired a rehabilitation of virtue concepts in normative theory, not only in contemporary virtue ethics but also in the other competing moral traditions, such as "virtue consequentialism" and "deontological theories of virtue."

Unlike Kantians, virtue ethicists have reservations about principles and rules as comprehensive guides to practice. Principles have exceptions. They work like a road map in the sense that they take us to the right city but they do not take us to the right street. Knowledge of general moral principles is not sufficient for sound decision-making; we need to know what to do in each particular situation. ${ }^{6}$ That does not mean that virtue ethics rejects the guidance of rules. The claim that there are correct principles is entirely consistent with the claim that they may not always be adequate guides to action (Foot, 1981). And virtue ethicists do endorse so-called be-rules ("be honest", "be generous", "be loyal", etc.) and Hursthouse's "v-rules," which can be formulated by employing virtue and vice terms ("do what is honest"; "do not do what is dishonest", etc.).

Unlike utilitarians, virtue ethicists care not only about the consequences of an action but also about how the action is brought about and by whom, that is, the relations between the agent's projects and his or her actions. The preservation of the person's psychological identity and moral integrity is a central concern in virtue ethics regardless of the good or bad states of affairs the person's act may produce. ${ }^{7}$ And even if it were psychologically realistic to expect humans to be utilitarian agents who abandon their "ground projects" for "the impartial point of view," virtue ethicists argue that we do not want a human being to be just a conduit for the furtherance of others' initiatives and purposes (Smart and Williams, 1973).

\section{VIRTUE AND THE IS-OUGHT GAP}

Prominent topics a long time ago, character and virtue lost their reputation in philosophy and psychology. In philosophy, character lost its charm during the nineteenth century. Principles prevailed over character as scientists began to claim that science was about scientific principles explaining events rather than about the features of substances explaining the activities of things (Anscombe, 1958). In psychology, there was a shift of attention away from character towards the allegedly value-free notion of personality in the 1930s, when the social sciences decisively moved to split scientific facts from moral value, following a dominant trend in the development 
of the social sciences. Personality traits were separated from character traits, the former as scientific phenomena, the latter as normative statements. Consequently, character — a moral term — was gradually substituted by personality — an allegedly amoral, value-free term (Haidt, 2006). In the end, Anscombe (1958) and Maslow (1954) initiated the re-emergence of character in the 1950's in Anglo-American philosophy and psychology.

Today, philosophers keep talking about character traits and psychologists about personality traits. But what is the difference? It might be helpful to first consider what we mean by the notion of a trait. A physical trait—say, "big"—-describes a person's physical features or physical abilities. A personality trait—say, "extrovert"- - focuses on one's personality. Personality traits, as studied by psychologists, are distinguished from character traits, which are the main concern of virtue ethicists. Character traits are a subset of personality traits that have bearing on moral matters (Gert, 1988; Brandt, 1970). This understanding is initially suggested by Aristotle when he distinguishes virtue and moral goodness from other aspects of our inner selves because only the virtues are matters of choice. While some virtue ethicists hold that the character traits of interest for virtue ethics supervene on the traits studied by personality psychologists (Solomon, 2005; Hartman, 1998; Moberg, 1999), ${ }^{8}$ others stress the distinction between character and personality, arguing that two people may be radically different in personality yet quite alike in moral character (Kupperman, 1991; Audi, 1995).

Both social scientists and ethicists aim to contribute to the consolidation of the virtue approach, but they keep sending conflicting messages. The fact that philosophical theorizing parted ways with psychological research on the virtues takes us back to the old divide between facts and values, that is, between scientific psychology and moral psychology (Doris and Stich, 2005). And the split between social scientists and ethicists on the nature of virtue mirrors the dichotomy between empirical and normative approaches to business ethics research, with the social scientists describing the antecedents and consequences of certain traits and behavior and the philosophers advocating for the character traits a person needs in order to flourish as a human being (Alzola, 2011).

This lack of integration creates quandaries and ambiguities in the theoretical conceptualization and the empirical operationalization of virtue constructs (Bright et al., 2011). Conflicting streams of research provide different and incompatible lists of virtues, different rank orders, and incompatible theories of the virtues, because they conceptualize and measure two different things using the same label. But, I shall argue, virtue is not polysemic. ${ }^{9}$

Why does this matter at all? At least for the following four reasons. First, we need an unambiguous conceptualization of what a virtue is in order to make progress in virtue theory (Von Wright, 1963). Second, the conceptualization of virtue is the battlefield where competing moral theories struggle for the normative priority of deontic and aretaic notions (Williams, 1985; Wallace, 1978). Third, the plausibility of empirically grounded objections against virtue ethics depends on an accurate understanding of what virtue is (Doris, 2002; Harman, 2003). Finally, the academic fields of management and psychology need an uncontroversial notion of virtue in order to identify plausible measures and indicators of "character strengths" and "virtuousness" in organizations (Cameron \& Spreitzer, 2011; Lopez \& Snyder, 2011). ${ }^{10}$ 
What, then, is virtue? Let us start with Aristotle's position on the genus of virtue, arguably "one of the less contentious in the history of the concept" (Zagzebski, 1996: 102). Virtue, in Aristotle, is a condition of the soul. There are three conditions of the soul, namely, passions, capacities, and states. Aristotle argues that neither the virtues nor the vices are passions, because we are not called good or bad on the basis of our passions. We are neither praised nor blamed for our passions, but rather for our virtues and our vices. Virtues and vices are not capacities either, for we are not praised or blamed for the simple capacity of feeling the passions. Thus, Aristotle defines a virtue as a state of character (NE, 1106a13-14).

More needs to be said about this definition. What sort of "states of character" do the virtues comprise? How different are they from the "character strengths" measured by psychologists and organizational scholars?

The virtues have been conceptualized as habits (Dewey, 1922; Ryle, 1949; Nussbaum, 1999), skills or abilities (Sigdwick, 1981), sentiments (Rawls, 1971), tendencies (Wallace, 1978; Kamtekar, 2004), inclinations (Kant, 1996), dispositions (Doris, 2002; Harman, 2000), and character traits (von Wright, 1963). Elsewhere, I have developed an account of virtue, which distinguishes its constitutive elements and dimensions. ${ }^{11}$ For simplicity, here I shall define virtue as a character trait and provide a general characterization of its components.

To say that someone possesses a certain character means that he has appropriate and integrated framing capacities, beliefs, desires, feelings, motivations, and behavioral tendencies. Take the virtue of courage. The courageous person is "the person who fears the right things, from the right end, in the right way, at the right time, and is correspondingly confident," Aristotle says (EN, 1115a17-18). A virtue, then, has four elements, namely, an intellectual, ${ }^{12}$ an emotional, ${ }^{13} \mathrm{a}$ motivational, ${ }^{14}$ and a behavioral ${ }^{15}$ component. Attributing the virtue of courage to someone—saying that someone is a courageous person—entails the following four claims:

1. He has developed appropriate framing capacities and deliberative skills to understand the presence of danger, he holds correct beliefs, and he deliberates carefully about how to respond to frightening conditions, including death (intellectual dimension).

2. He feels the appropriate level of fear, neither more nor less of the right things. He fears the things that deserve to be feared and not just any bad thing that may possibly happen (emotional dimension).

3. He stands firm against what is painful out of the right motivations and in service of the right ends, not because he fears the reproach of his fellows or expects a reward from the beneficiary of his actions (motivational dimension). And, finally,

4. He successfully stands against frightening things; he is disposed to be unperturbed when facing things that are not too frightening, and he typically succeeds in responding appropriately to frightening conditions on the basis of the constituent understanding, feelings, and motivations (behavioral dimension). 
It follows from this that it makes sense to distinguish — as in the title of this articledoing the virtuous action from having a virtuous character. In EN II. 4, Aristotle contrasts the value of acting from craft knowledge-which is purely instrumental, as a means to the right product - and the value of acting from virtue. The goodness of production is established by its usefulness for producing the right sort of product, but the value of virtue is not simply determined by its efficient production; it is intrinsic. A virtuous action has a characteristic motive; it is not simply a means to some further result. And while a product may be produced well even if not produced by a good craftsman, an action is virtuous only if carried out by a good agent (and from the right state of character).

This is where virtue concepts become especially helpful. Virtue attribution serves, I submit, three distinctive purposes, namely, descriptive, explanatory, and evaluative functions (Alzola, 2012):

- Description: first, virtue attribution provides a short way to summarize how one person differs from another person, that is, a way to describe the state of a person's soul. The descriptive function of virtue-attribution consists in classifying and categorizing a person's psychological makeup. For example, ascribing the virtue of courage to a person summarizes a history of mental states and actions in the past as well as highlights individual differences. ${ }^{16}$

- Explanation: second, virtue attribution has an explanatory role, that is, the possession (or lack) of a certain character trait explains (partially) the possessor's beliefs, desires, emotions, motivations, and behavior. An explanatory ascription of virtue carries a commitment to the existence of some causal mechanism. One of the reasons why a person feels some apprehension about visiting the dentist-one of the reasons that explains why he or she is consistently putting off the needed appointment-is the virtue of courage, or the lack thereof. Traits are supposed to be explanatory in that it will, at least sometimes, be correct to explain actions in terms of character traits and not just in terms of situational features. ${ }^{17}$

- Evaluation: third, a virtue is an acquired excellence; it is a matter of choice and achievement; it is something that we admire in a person. The value of a virtue is attached directly to the possessor and secondarily to his or her deeds. Hence, virtue attributions perform an evaluative function. Virtue attributions are forms of normative assessment. ${ }^{18}$

Virtues are thick ethical concepts in which facts and values are entangled, such that they can be and are employed in explanations and evaluations of agents and their actions (Putnam, 2002). As a thick ethical concept, when a virtue is used in judgments (by the right kind of agent), it has the feature that the judgment as a whole is both responsive to how the world is and gives the agent reasons for action (Williams, 1995; McDowell, 1998). We say that a man rescued a drowning child because he is courageous, or opportunistic (because, say, he is trying to impress his girlfriend), or greedy (because, say, he expects a big reward in return), or suicidal. And these are all ways of describing and explaining what he did as well as ways to assess his character. ${ }^{19}$ 


\section{VIRTUE AND REDUCTION}

A quick glance at what ethicists, positive psychologists, and management scholars have recently written about virtue may create the impression that they all constitute contributions to a unitary tradition about a single concept. But, as suggested above, they are not.

There are, at least, two basic strategies to conceptualize virtue, namely a reductive and a non-reductive approach. ${ }^{20}$ Some philosophers—notably Ryle (1949: 43) but also Brandt (1970: 27), Frankena (1973: 65), Beauchamp and Childress (1983: 261-5), Becker (1986: 42), Carr (1988: 186), and Rawls (1971: 192), among others-and most psychologists and organizational scholars (Ross and Nisbett, 1991; Peterson \& Seligman, 2004; Cameron, Dutton, and Quinn, 2003; Cameron \& Spreitzer, 2011; Goodwin, Piazza, \& Rozin, 2014), explicitly or tacitly (and oftentimes unintentionally) hold a reductive account of the virtues, according to which virtues are, roughly, behavioral dispositions to act in conformity with certain rules of action.

Generally, we say that an object has a certain disposition if and only if the object would produce the associated manifestation when under the conditions of manifestation (Fara, 2005; McKitrick, 2005). Hence, a disposition is an entirely hypothetical property that makes references to counterfactual states of affairs (Armstrong, 1969; Armstrong, Martin and Place, 1996; Bird, 1998; Cross, 2005).

The dispositional or reductive view holds a linear conception of virtue, whereby a virtue is a single linear trait that bears a one-to-one correspondence with certain behavior in any situation where it is relevant (Hampshire, 1953; Bird, 1954; Brandt, 1988). Whether a trait is indeed a virtue or a vice is established, the argument goes, by reference to the moral rule that determines the quality of the action associated with that trait. According to the dispositional view, the virtue of honesty can be reduced to a disposition to obey the moral rule that forbids someone, among other things, to tell lies or intentionally deceive others. Likewise, the virtue of benevolence is fundamentally a disposition to perform actions in accordance with the duty of benevolence.

There are two polemics over reductionism, namely, a philosophical polemic over the reduction of virtue to duty categories and a methodological polemic over the reduction of virtue to actions in empirical studies. The first polemic is concerned with the priority of deontic or aretaic concepts in the conceptualization of virtue: while some philosophers take deontic concepts such as "ought," "right," and "duty" to be the fundamental concepts of ethics (and so define virtue in terms of deontic notions), others take aretaic notions such as "admirable" and "excellent" to be the fundamental ones. The second polemic is about the role of character in the conceptualization of virtuous actions: while some psychologists define a virtuous action in terms of the qualities of the action, others are more concerned with the agent performing the action. So, the first raises the question whether the reduction of virtue to deontic categories fails to treat character seriously. And the second raises the question whether reducing virtue to actions may lead to either blindness 
to virtue-where it may actually be present—or seeing virtue where there is none, because factors behind relevant behavior are overlooked. ${ }^{21}$

The reductive view can be said to comprise two distinctive theses: a normative thesis and an observational thesis.

The normative thesis holds that virtues are dispositions to act in conformity with certain rules. For example, in the consequentialist camp, Sidgwick famously argues that the virtue of veracity involves "a settled endeavor to produce in the minds of others impressions exactly correspondent to the facts, whatever his motive may be for so doing" ([1907] 1981: 224). And Driver holds that virtue "is a trait of character that we value because we recognize its good-producing qualities (1996: vii). Likewise, deontologists claim that "moral virtues are dispositions to avoid unjustified violations of the moral rules" and that "to have a moral vice is to have a disposition to unjustifiably violate a moral rule." (Gert, 2005: 184) In sum, the reductive view defends the claim that "to have a moral virtue is to be disposed to act as moral rules direct." (Gewirth, 1978: 339)

The observational thesis holds that virtue entails an expectation of consistent behavioral manifestations of the virtue as a necessary condition of its existence. Pervin claims that "a kind person will act kindly even when there is no situational pressure or external reward for doing so, thus suggesting some kind of internal process or mechanism that is producing the behavior" (Pervin, Cervone, \& John, 2005). A virtue is a "relatively stable and long-term disposition to act in distinctive ways" (Harman, 1999: 317). Or, as Doris approvingly quotes from Woods (1986: $149)$, it is "a disposition to act unfailingly in a virtuous manner" (2002: 176). ${ }^{22}$ Character attribution is, according to this position, a means of saying that the person will act in a certain way across time and situations (Epstein, 1984; Ajzen, 2005). ${ }^{23}$

Whether done purposely or not, psychologists in practice endorse the reductive view. ${ }^{24}$ They do so presumably because the conceptualization of virtues as behavioral dispositions makes their job easier in terms of operationalizing the constructs that are supposed to be the virtues. Personality psychologists can be said to understand virtues as behavioral dispositions in that they are more focused on classifying behavior than theorizing about mental states. For instance, there is extensive research on a classificatory scheme in personality psychology (Cattell, 1943; Eysenck, 1991; Costa and McCrae, 1985) that attempts to identify a minimum number of dimensions along which people differ by using factor analysis techniques on questionnaire data rather than by using a priori conceptualization..$^{25}$

Positive psychologists also define character strengths in behavioral terms (Seligman and Csikszentmihalyi, 2000, Seligman, 2011). For example, Peterson and Seligman define character strengths as "the psychological ingredients-process or mechanisms - that define the virtues" or "distinguishable routes to display one or another of the virtues" (2004:13). To illustrate this claim, they argue that the virtue of wisdom can be achieved through such strengths as creativity, curiosity, love of learning, and open mindedness. In their seminal work, they conclude that someone is of good character if he or she displays the strengths within a virtue group. A character strength, then, must meet some criteria in order to be 
considered a virtue. ${ }^{26}$ The following five criteria are the most relevant features for the purpose of this section (Peterson and Seligman, 2004: 17-24):

1. Character strengths are like personal traits that a person owns, celebrates, and frequently exercises. ${ }^{27}$

2. "Each strength is morally valued in its own right, even in the absence of obvious beneficial outcomes."

3. "The display of a strength by one person does not diminish other people in the vicinity."

4. "A strength needs to be manifest in the range of an individual's behavior... it should be trait-like in the sense of having a degree of generality across situations and stability across time."

5. Another criterion for a character strength is that people differ in their strengths.

Along the same lines, organizational scholars working on the Positive Organizational Scholarship tradition endorse the dispositional analysis of character strengths as virtues, although they seem to do so for pragmatic reasons. Scholars in this tradition are developing an array of instruments to measure character strengths (Cameron, 2013), so they basically adopt the positive psychology's framework without any conceptual analysis of the nature of such character strengths.

Both positive psychologists and POS scholars define virtue in behavioral terms. For example, the commendable work on the character strength of courage in the POS tradition (Worline and Quinn, 2003; Worline, 2003) is primarily concerned with courageous behavior. In the absence of conceptual analysis, one has reasons to believe that POS scholars understand the virtue of courage as a disposition to act following a principle of courage, which would go along the lines of overcoming fear and voluntarily engaging in worthy action. In their words: "the effectiveness of each organizational form may only be viable over the long term if participants exercise the courage necessary to act from principle" (Worline and Quinn, 2002: 157). In the same vein, POS research on the character strength of compassion in the workplace is defined as "an expression of an innate human instinct to respond to the suffering of others" (Dutton, Worline, Frost, and Lilius, 2006: 60), and POS research on the character strength of gratitude assumes that gratitude is just a behavioral disposition to act according to the principle of expressing thanks for the benefits one has received. As Emmons puts it, "in psychological parlance, gratitude is the positive recognition of benefits received" (2003: 82).

One can certainly understand the need for some degree of reductionism by empirical researchers. One of the most decisive arguments in favor of the reductive approach in positive psychology and POS is that it makes conducting empirical studies on character strengths easier. (Bright, Winn, \& Kanov, 2014). The claim is that we do not need to provide a conceptual analysis of virtue because trait attributions are made - according to the reductive model — purely on the evidence of behavior. Why so? Because the classification of types is based on observable behavioral regularities, which are made for the purpose of predicting future behavior. Then, even if behavior is caused by internal factors, we do not need to know those factors; we can 
classify people and make predictions without recourse to them. Consequently, the reductive view holds that the only emphasis on explanation should be at the level of behavior, whatever the underlying causes of behavior. Given that trait attribution has a one-to-one correspondence with individual differences - so the reductive argument goes - there is no need to distinguish between trait attribution and the underlying individual differences that cause behavior. Peterson and Seligman suggest this point:

We disavow all intents to propose a taxonomy in the technical sense, even though previous drafts of our work used that term. A modest description of our endeavor-an aspirational classification of strengths and virtues-preserves the flexibility necessary to proceed. A thoughtful classification, even if tentative, will serve the goals of psychology more productively than a flawed taxonomy, even if the surface entries look exactly the same. We trust to the emerging field of positive psychology as a whole to create one or more theories that will conceptually unify our classification (2004: 7).

For the time being, such a theory (or theories) does not exist.

Now, what about the philosophers who advance a reductive theory of virtue? Unlike the psychologists who may be unaware of what is at stake here, philosophers do know what reduction amounts to. Why are these highly competent philosophers-who would not think of embracing behaviorism in the realm of perception and thought-behaviorists about virtue? We have reasons to suspect it is because they do not think virtues amount to anything interesting; they are committed to the claim that virtues do not add much to moral theory (to the sort of moral theory they advocate).

There are, in sum, at least two basic ways to conceptualize virtue, namely a reductive and a non-reductive approach. Most psychologists and organizational scholars, as well as a number of (non-virtue) ethicists, endorse the reductive (or dispositional) conception of virtue, which entails a twofold claim, namely:

(A) virtues are behavioral dispositions to act as moral rules direct (Gewirth, 1978) and

(B) virtues reliably lead to trait-relevant behavior in the appropriate eliciting conditions (Doris, 2002).

It follows that, under the reductive view, moral virtues derive their content and normative force from deontic concepts. In other words, virtue concepts have merely an instrumental, secondary role in moral theory (namely, to ensure conformity with the right moral rules).

\section{WHAT IS WRONG WITH REDUCTION?}

In spite of its ostensible practical advantages, there are four serious objections against the reductive account of virtue.

First, the reductive account has weak explanatory power and, hence, virtue attributions do not offer good explanations of behavior in organizations. The reductive account provides a simple, linear model of virtue. Under the reductive model, ascribing a virtue entails placing an individual on a ranking according to how much trait-relevant behavior the individual exhibits. Consider the virtue of honesty. In the 
famous studies on academic cheating, Hartshorne and May (1928) measured cheating by counting how many points a child adds to his or her score when marking his or her own test. Each observation is supposed to provide a representative measure of the virtue, which must correlate with quantitative measurements of other behaviors that supposedly measure the same trait in other scenarios. According to the reductive view, a child who is honest will be consistent in not adding points. And the more dishonest a child is, the more points he or she will necessarily add. Ultimately, the number of points added is the measure of dishonesty, which is supposed to be consistent across situations and time for each child. The same sort of dispositional analysis is used to attribute virtues such as benevolence, compassion, and others in the experimental literature in social psychology (Isen and Levin, 1972; Darley and Latane, 1968; Latane and Rodin, 1969; Darley and Batson, 1973; Milgram 1974) and organizational behavior (Trevino and Youngblood, 1990; Staw, Bell, and Clausen, 1986; Chatman and Barsade, 1995; Barrick and Mount, 1991).

The reductive strategy has weak explanatory power because it does not have much to say about the interaction of more than one disposition. People are more complex than the reductive account suggests. Human beings have multiple dispositions that might lead to conflicting courses of action. But the reductive strategy does not take into account the possibility that two different traits, thought of as internal individual differences, may come into conflict in a particular situation. A number of different character traits may be associated with a particular behavior; for example, the virtue of honesty and the virtue of loyalty may be both associated with truth telling. Conversely, a single trait may explain inconsistent actions; for example, the virtue of integrity may regularly lead to truth telling but in other cases may require lying (e.g. in case of a serious emergency). Finally, there might be conflicting traits leading to a single behavior (Sabini \& Silver, 2005). If two or more virtues conflict in a situation, behavior may appear inconsistent, but that is just an illusion resulting from assessing behavior with reference to one single trait (Alzola, 2012). ${ }^{28}$

Consider someone who is utterly fearless in two different situations. In the first, the person is being assaulted by an unarmed mugger; in the second, he is being assaulted by six armed muggers. That person's state of mind is in some obvious sense identical in the two cases, but whereas in the first case he is showing couragei.e., a virtue - in the second case he is showing foolhardiness-i.e. a vice. When we say that virtue is a mean, we are referring to the when, the how, the to whom, etc. in which an action may happen. So, virtues do not supervene merely on psychological states but rather on psychological states in contexts. A courageous person may experience fear in the case of the many muggers but not in the case of the one or may run in the first case but not in the second and still be a virtuous person exhibiting virtue in both cases. ${ }^{29}$

The second objection holds that a dispositional account of the virtues does not have much to say about the interaction of traits and other mental states in explanations of behavior. If a belief is a tendency to do a certain act given a certain desire, and a desire is a tendency to do a certain act given a certain belief, a reductive account does not provide a good answer for why a person performed (or failed to perform) such an action given his or her desire to perform that action and his or her beliefs that such an 
action leads to the desired outcomes (Kupperman, 1991). To illustrate this claim, consider the previously mentioned experiments in social psychology. If a belief that one must help someone in need (if possible) ${ }^{30}$ is a tendency to help someone in need given a certain desire to help someone in need, and a desire to help someone in need is a tendency to help someone in need given a certain belief that one must help someone in need (if possible), then, the subject's failure to help someone in need does not provide any explanation of his or her behavior. The commonsense solution - that the agent can probably tell us what he or she wants and what he or she believes-is unattractive to the scientist who does not countenance inner states reportable by the agent. ${ }^{31}$

The third objection holds that a reductive account of virtue does not provide the resources to account for virtue attribution in the absence of behavior. Specifically, the reductive account is question-begging when it comes to assess virtues in the absence of the typical behavioral manifestations associated with the virtue. Aristotle argues that "(...) it seems possible for someone to possess virtue but be asleep or inactive throughout his life..." (EN, 1095b34-1096a2). The possession of a good character trait may not have an external manifestation, for example, when environmental conditions do not provide the opportunity for the trait to be displayed, regardless of the strength of the trait (Sonnentag \& McDaniel, 2013). This claim will surely be resisted by reductivists. ${ }^{32}$ As explained in the previous section, thesis (B) of the reductive account holds that it makes no sense to attribute a certain character trait $\mathrm{X}$ to a person who has never behaved in an X-like manner (Alston, 1975; Doris, 2002). The person's failure to act according to virtue is enough to prove that he or she does not possess such a virtue (see footnote 23 above). And the person's action, conforming to the moral rule or principle, is necessary as evidence of virtue.

Regrettably, the reductive account blurs the very important distinction between character attribution and the evaluation of actions, that is, between the possession of a virtue and an action in conformity with virtue. For example, positive psychologists, on the one hand, claim to be concerned with the notion of "a virtuous person" (Seligman, 2002: 137), but then they write "we are comfortable saying that someone is of good character if he or she displays but 1 or 2 strengths within a virtue group" (Peterson and Seligman, 2004: 13). And POS scholars are satisfied with what they called virtuousness, which is a new label for what philosophers would plainly call "right action." Even if it were possible to infer a person's character from a single action, ${ }^{33}$ a theory that is committed to the claim that virtues are just statistical measures of past behavior fails to capture the robust meaning of virtue as an excellence of character, which is the fundamental concept in the virtue ethics tradition.

The fourth objection is that if virtues are reduced to dispositions to follow certain ethical rules, the essence of virtue is lost, so we do not need any talk of moral virtue. The reductive view is serving the cause of rule-based normative theories and thereby misusing the language of virtue. If morality is just about rightness, if the fundamental question of morality is the question of what to do, then it follows that duties and principles have normative priority (and character has a secondary role in moral theory). The reductive strategy advises us to find and justify fundamental rules and principles. The moral virtues have, at most, an instrumental role. 
One ought to develop certain dispositions to reliably act in conformity with such rules and principles (Harman, 2001). As a result, the reductive account does not give us the tools to account for a critical distinction between acting from virtue and acting in conformity with virtue (Audi, 1995). Acts that are merely in conformity with virtue may qualify as instances of what the POS scholar calls "virtuousness" (Cameron \& Winn, 2011; Bright, Cameron, \& Caza, 2006), but they are not genuinely virtuous. For only actions from virtue bespeak a feature of good character (Korsgaard, 1996).

Even the most dishonest person could perform what looks like an honest action (for the sake of a reward, for example) and even a coward could perform a pseudo-act of courage - done for the sake of impressing bystanders (or done under the influence or by mistake). If the person's motives behind his or her actions are irrelevant to the evaluation of his or her actions, then it follows that we do not need a talk of virtue at all. Neither do we need character. The language of rightness would be enough to do the job.

In a sense, the reductive account is the sort of "ethics without persons" that some scholars advocate (Doris, 2009). But it was precisely as a reaction to the ethics-without-persons idea that the contemporary virtue ethics tradition has been developed since 1958! Virtue ethics is an ethics of being, of being good as a person.

\section{REAL VIRTUE}

When taken together, the four previous objections make a strong case against reduction. But discrediting the reductive account of virtue is only half the story. We need to examine what a non-reductive strategy of virtue has to offer and make a case for the claim that a comprehensive account ${ }^{34}$ does not fall to the four aforementioned objections. I began articulating that account elsewhere (Alzola, 2012). Here I shall briefly outline the framework and extend it to distinguish virtue from "character strengths" and "virtuousness."

A non-reductive account holds that a virtue is not a disposition to behave in accordance with certain rules of action. For an action to be from a state of virtue-for an action to bespeak a mark of good character-it must be expressive of appropriate inner states. The reductive account reduces virtue to its behavioral aspects, thereby neglecting its inner dimension. Virtue ethicists, on the contrary, highlight the understanding of virtue as "an inner quality of an agent and of his acts" (von Wright, 1963), thereby integrating the cognitive, the emotional, and the motivational components of virtue. What constitutes an honest person, for instance, is not exhausted by any catalogue of possible honest actions he or she may perform. Being honest involves qualities of character proper to the honest person, and it is these qualities that establish what actions honesty requires.

If virtuousness is "conduct that conforms to an accepted standard of right and wrong," then virtuousness cannot be "virtuous" because an action in conformity to virtue does not necessarily bespeak a feature of good character.

Virtue is not merely knowledge about what is courageous, just, or honest. Neither is it only the ability to align one's desiderative states with what one believes. It is not 
only being motivated to do what is courageous, just, or loyal for the right reasons. Neither is it just a disposition to do what is courageous, just, or honest. Virtue is all of these or it is nothing. Thus, when seen through the notion of virtue articulated in Section Two, the reductive strategy is conceptually inaccurate and methodologically misleading.

My conception of virtue is non-reductive because it holds that the four elements of character are not reducible to each other. Although they are interrelated, none of them can be described solely in terms of one of the others. The virtues, in sum, cannot be plausibly reduced to dispositions to behave in conformity with certain principles and rules without losing the substance of the very idea of virtue.

Because it can accommodate the interplay of multiple virtues as well as the interaction between virtues and other mental states-by integrating the cognitive, emotional, and motivational components of virtue to understand the agent's action-a non-reductive approach to virtue has greater explanatory power than the reductive view. ${ }^{35}$ And because it is concerned not only with behavioral tendencies but also with the other three dimensions of virtue, a non-reductive account to virtue fares better than the dispositional theory when it comes to assessing cases of virtue attribution without behavior. For example, even if the situation does not provide the opportunity for behavioral manifestations, the agent may frame (or fail to frame) the situation appropriately, he or she may experience (or fail to experience) certain emotions (from anger to remorse) in response to the situation, he or she may deliberate and make proper judgments, etc. Virtue does not necessarily require "trait-relevant behavior in the appropriate eliciting conditions." ${ }^{36}$ Depending on the scope of "appropriate," we might say that the absence of such behavior calls for an explanation. But an action-understood as the presence of such a behavioral manifestation-is not sufficient to infer the presence of a virtue (Aristotle, EN 1105a25). More needs to be said about the motives and intentions of the person, about his or her deliberation and reflection, about his or her emotions and values, and about his or her ends and motives (Nussbaum, 1988). Moreover, the reductive account rests on a distinction between virtue and virtuous action that is unintelligible. And because the non-reductive account is definitionally character-based, it recognizes the normative priority of aretaic concepts over deontic notions. Acting virtuously, acting from virtue, is just a way to align the four dimensions of virtue identified in Section Three.

Can virtue, understood in this non-reductive way, be measured? A complex question requires a long answer. In principle, it depends on whether the four dimensions of virtue can be further analyzed independently of each other. If the comprehensive account of virtue defended in this section can be broken down into separate parts, and if it is methodologically feasible to examine virtue as a cluster of separate yet integrated components, then the answer is "Yes."

Most virtue ethicists - especially those who endorse the unity of the virtues thesis (e.g. von Wright, 1963; Irwin, 1988; Cooper, 1998, McDowell, 1998) ${ }^{37}$ —will be against this approach. Still, some virtue scholars—such as Robert Adams and Nancy Snow-may be more optimistic.

Adams (2006) favorably considers the possibility of micro-virtues that come in "modules," that is, independent component parts from which a complex and 
more general structure is or can be assembled. Some domain-specific behavioral dispositions-for example, a disposition to behave honestly or courageously in only a single area of life such as one's professional life, when motivated by a proper appreciation of the values of professional honesty or courage—can be, according to Adams, "modules of virtue." Such modules might be added together to form a more complex and general disposition that may qualify as virtue..$^{38}$

Snow (2010) suggests decomposing virtue into three measurable parts, which she calls virtue intelligence, dispositionality, and behavior. She claims that virtue intelligence can be operationalized through the measurement of the agent's sensitivities and abilities to recognize and generate appropriate responses in the cognitive, affective, and behavioral domains (Snow, 2014). These sensitivities can be measured using techniques that keep track of people's perceptions of virtue-relevant stimuli in actual or fictional social interactions. One example is to ask people to watch a clip of another person's social interactions and hit a button any time they observe a virtue-relevant stimulus. Upon completion, the investigator will ask the participants to go back through their hits and explain what they take the virtue-relevant stimuli to be and why. Another idea is to use diary methods whereby the investigator asks people to recall virtue-relevant stimuli from their past experiences and how they responded to such stimuli. Participants' responses can be recorded using daily diary entries or portable electronic devices. The inspiration for these and other ideas to measure different components of virtue is the work of psychologist Matthias Mehl and his collaborators (Mehl and Conner, 2012). Mehl has pioneered the use of a computerized tape recorder, known as the Electronically Activated Recorder (Mehl \& Pennebaker, 2003), "to record and analyze virtue-relevant behavior in daily life." Specifically, they are using the EAR to test "the stability, variability, and changeability of virtuous daily behavior relative to (non-virtuous) neutral and negative daily behavior using a novel, naturalistic observation sampling method" (Snow, 2014: 26). ${ }^{39}$

Full elaboration of this point would deserve its own paper. ${ }^{40}$ What we must retain is that in virtue ethics, there is no virtuous action without a virtuous person. We are to understand what it means to behave virtuously through the study of the nature and inclinations of the virtuous person, not through the observation of seemingly virtuous actions. In other words, we do not define virtuous actions as those that conform to certain moral rules and, then, define a virtuous person as one who reliably and characteristically perform such actions. Qualities of character are normatively more basic than rules and actions.

Being virtuous and acting like a virtuous person must be distinguished, because even the most vicious person may behave like the virtuous one. The reductive account does not have the resources for a negative evaluation of the vicious person's actions. In contrast, according to the non-reductive view, a person who is virtuous has a standing commitment to acting from virtue, in the sense that her cognitive, emotional, motivational, and behavioral states are all well aligned. Importantly, under the non-reductive view virtue is more than just continence: the continent person actually fears what should not be feared — a trip to the dentist—and overcomes this fear but the courageous person simply does not fear it at all. To be virtuous is to be without fear where courage is called for; to be continent is to overcome one's fear (EN 1119a10ff). 


\section{GRATITUDE AND THE GRATEFUL PERSON}

One might object that much of my argument relies on distinctions that may not make a significant difference in practice. In this section, I shall illustrate the differences between the reductive and the non-reductive accounts by discussing an example of a well-regarded virtue: the virtue of gratitude. We could apply this framework to any other virtue - elsewhere I have examined honesty and compassion (Alzola, 2008, 2012) and in the section above, I have suggested how to analyze the virtues of courage and benevolence-but gratitude makes it easier to compare reductive and non-reductive approaches.

According to the "Values in Action Inventory of Strengths" (VIA), gratitude is defined as "being aware of and thankful for the good things that happen; taking time to express thanks" (Peterson and Seligman, 2004: 30). ${ }^{41}$

Gratitude has a very important place in the POS literature. It is hypothesized to lead to positive individual and organizational outcomes, such as mood and prosocial behavior, and also to serve as an antidote to "toxic workplace emotions," such as anger and envy (Emmons 2003: 90).

Psychologists predominantly use two instruments to "scientifically measure gratitude," namely, the GQ-6 (Gratitude Questionnaire-6) and the GRAT (Gratitude, Resentment, and Appreciation Test) (McCullough, Emmons, \& Tsang, 2002; Watkins, Woodward, Stone \& Kolts, 2003). The studies apparently indicate that gratitude is a reliable predictor of subjective well-being and other positive qualities felt by the beneficiary (Emmons and McCollough, 2003; Algoe, Haidt, \& Gable, 2008; Bartlett, Condon, Cruz, Baumann, \& Desteno, 2012). Designers and users of these instruments claim to have used "strong theoretical grounds to develop an a priori conception" of gratitude (Wood, Maltby, Stewart, and Joseph, 2008). Yet, according to a study of recent papers on gratitude in psychology, most of them merely rely on definitions by established scholars-notably, Emmons and McCollough-without providing a conceptual analysis of what gratitude is. And some studies do not even offer a definition of gratitude, although they examine its correlates and positive benefits! (Kristjansson, 2013).

Following the reductive strategy, one would define the virtue (or character strength) of gratitude as a disposition to follow a rule of action, which would go along the lines of a duty of gratitude (Emmons, 2004). In turn, one could define the duty of gratitude as a Rossian prima facie duty: "We should express gratitude, in deed or at least in words of thanks, in a way that befits good things done for us by other people, where, other things equal, our obligation is stronger if what was done for us was not owed to us" (Ross, 2002; Audi, 2009). Or, in the positive psychologist's version, the duty of gratitude is defined as requiring that anytime one is benefited by another person, one ought to recognize the benefits received and express gratefulness (Emmons, 2003: 82). Then, the virtue of gratitude would be a disposition to act in conformity with the moral duty of gratitude (Emmons \& McCullough, 2004; Lambert, Graham \& Fincham, 2009).

The problem is that the reductive approach fails to describe gratitude in the way we colloquially speak of it and the way virtue ethicists understand the 
virtue of gratitude. For, even if it is true that a malevolent person may perform an act that looks like an act of benevolence, and even if a coward may perform an act that looks like a courageous act, in the case of gratitude it seems that the very notion of gratitude is tied to the inner component of the virtue (Walker, 1988; McAleer, 2012). What constitutes an act of gratitude is indeed the motive from which it is done, that is, the intellectual, emotional, and motivational qualities of character of the person, besides his or her behavior (Berger, 1975; Fitzgerald, 1998). ${ }^{42}$

In other words, in order to perform an act of gratitude, one must be grateful. It is not sufficient to perform the action that is required by the duty of gratitude. Acting from such a duty cannot serve as a substitute motive without significantly altering the nature of an act of gratitude. Even if we agree that an act of insincere gratitude is better than manifesting no gratitude at all-although the case for this has yet to be made - the existence of a duty to act as if one is grateful fails to capture the essence of the virtue of gratitude (Card, 1988). Consequently, a disposition to act in conformity with a duty of gratitude is not going to do the work of gratitude as a virtue (Wellman, 1999).

In order to perform an act of gratitude, a person needs to be grateful, i.e., he or she needs to possess the virtue of gratitude. What makes an act into an act of gratitudewhat makes us admire such an act as a praiseworthy act - is the state of character of the person who performs that act. That state of character is what we know as the virtue of gratitude. Virtue concepts have, in sum, priority over deontic concepts.

The reductive account of virtue is blind to the mental process underlying an act of gratitude (Weiss, 1985). Hence, the view that gratitude — as a character strength-is simply a behavioral disposition to behave according to the duty of gratitude does not properly describe our experience of gratitude, and it does not align with the best philosophical account of the virtue of gratitude (Carr, 2013). Gratitude involves not only appreciating a favor and acting consequently but also appropriate inner states, including beliefs, desires, and attitudes towards one's benefactor. The virtue of gratitude has intellectual, emotional, motivational, and behavioral dimensions. It entails some framing capacities to grasp the goodness and benevolence of the benefactor's actions together with appropriate feelings and the willingness to be indebted to others (which requires other related virtues such as generosity and humility). ${ }^{43}$ Gratitude also involves appropriate desires to return acknowledging tokens of benefit.

Ultimately, gratitude may not require an external manifestation. A person may be grateful without expressing thanks. A person may (wrongly) be grateful for things that harm him or her. And sometimes a person may have reasons not to accept some benefits and to refuse to express thanks to a benefactor whose intention is blatantly wicked (Fitzgerald, 1998). For example, a benefactor may aim to cause harm to the beneficiary or third parties (Roberts, 1995).

Praise for gratitude and criticisms for failures of gratitude are invariably evaluations of the four dimensions of character. It is precisely this focus on good and bad character rather than unmet obligations and behavioral dispositions to act in conformity with such obligations that makes gratitude a virtue.

In sum, the virtue of gratitude does not conform to the reductive program, a form of behaviorism that fails to properly distinguish inner from outer states, cashing the 
former into the latter. An act of gratitude is characteristically defined as an action motivated by the virtue of gratitude. It cannot be performed from a sense of duty without significantly altering the nature of the action. As explained in Section Two, a virtuous action is virtuous precisely because of the intellectual, affective, motivational, and behavioral states from which it stems.

\section{CONCLUSION}

The re-emergence of moral character in the philosophical, psychological, and management literatures has reanimated an interdisciplinary research program on the value of virtue and its relationships with happiness, flourishing, and organizational behavior. It also complements recent research into character and virtue in the workplace and their insights into recruitment decisions, leadership styles, character education, integrity policies, and more. However, a weak conceptualization of its fundamental notions creates a number of ambiguities that hinder the evolution of this inquiry and prevent meaningful collaboration between philosophers and social scientists in business ethics.

In this paper, I have argued that there are two basic strategies to define virtue, namely, a reductive account and a non-reductive account of virtue. The reductive account defines virtues as behavioral dispositions to conform to certain rules of action. This amounts to the claim that all that matters in ethics is to identify the right principles and then develop the dispositions to act in conformity with such principles because character has a secondary place in moral theory. I submit that there are at least four decisive objections against the reductive account. In contrast, a non-reductive account holds that virtues are traits of character whose components cannot be reduced to any of the others. I hope I have made clear that at least some character strengths, such as the virtue of gratitude, do not conform to the reductive approach and, hence, cannot be reduced to dispositions to act in conformity with certain rules or principles because gratitude is fundamentally a matter of attitude, desire, and belief. Possessing the character trait of gratitude entails the cultivation of certain internal psychological states whose value is independent from the actions that result from them.

I hope I have substantiated the claim that the non-reductive account is the best philosophical account of virtue because it is a fair reconstruction of the Aristotelian project, because it preserves the normative priority of character in moral theorizing, and because it fares better than the reductive account not only in terms of the four objections previously discussed but also in accounting for our intuitions about the virtue of gratitude.

We cannot understand what virtue is or what it means to live virtuously without first understanding the virtuous person. And we can only appreciate virtue through studying the nature and inclinations of the virtuous person rather than his or her behavior in conformity with certain principles. We do not define virtuous actions as those that conform to certain moral rules and, then, define a virtuous person as one who characteristically achieves such standards. Qualities of character are normatively more basic than principles and actions.

It is a bit of an irony that the social scientists who argue for virtue and the normative ethicists who argue against virtue agree on a reductive conceptualization of virtue. 
Admittedly, psychologists and organizational scholars need to rely on operationalized definitions and measures that may end up jeopardizing the conceptual purity of their constructs (Cheng, 1997). But the social scientists who advocate the importance of virtue may benefit from considering the account of virtue that is defended by virtue ethicists (rather than the ones defended by their foes), even if the non-reductive account involves technical difficulties. ${ }^{44}$

In the end, social scientists may be more concerned with what is perceived as virtue (virtuousness) than with objective—or "authentic," to use the language of positive psychologists—virtue. But—contrary to what Haidt and other positive psychologists suggest on the emotions of disgust and elevation (Vianello, Galliani, \& Haidt, 2010; Algoe and Haidt, 2009; Algoe, Haidt, \& Gable, 2008)—what is perceived as virtue may be morally objectionable. Future research should address the distinction between perceived and authentic virtue, explore the interactions of virtues among themselves and between virtues and other mental states, carefully distinguish attributing virtue from classifying behavior, and explore the link between character and virtuous behavior. In order to make that distinction, we need a better and more refined notion of virtue and virtuous action; a notion that accounts for the non-instrumental value of character concepts. Desires, emotions, and actions that are characteristic of virtue are not mere means to living well. Rather, they are constitutive of living well; they are what count as living well. It is precisely for that reason that when we praise a truly virtuous action we do not simply value a reliable tendency to perform the action. Rather, what we value is the state of character that the person displays in his or her action.

Aristotle puts it nicely:

... what is true of crafts is not true of virtues. For the products of a craft determine by their own qualities whether they have been produced well; and so it suffices that they have the right qualities when they have been produced. But for actions in accord with the virtues to be done temperately or justly it does not suffice that they themselves have the right qualities. Rather, the agent must also be in the right state when he does them (...) Hence, actions are called just or temperate when they are the sort that a just or a temperate person would do. But the just and temperate person is not the one who [merely] does these actions, but the one who also does them in the way in which just or temperate people do them (EN, 1105a25ff).

\section{ACKNOWLEDGEMENTS}

Earlier versions of this paper were read to the Philosophy Department of Fordham University and to the panel on Virtue Theory at the 2014 meeting of the Society for Business Ethics in Philadelphia. The paper was also presented to the doctoral seminar in Business Ethics at Rutgers University in December of 2013. I received helpful suggestions on all of these occasions. Being an article on gratitude, I owe a large debt of gratitude to Ed Hartman, Daryl Koehn, Danielle Warren, and Kevin Jackson for discussion of ideas in this paper. I am also indebted to BEQ Associate Editor Ken Goodpaster and three anonymous reviewers for their insightful suggestions. I am also grateful to Beth Henzel for her useful editorial help. 


\section{NOTES}

1. Along these lines, a growing number of multidisciplinary research initiatives are sponsoring contributions from teams of investigators working within the humanities and the sciences. The goal is to begin a new field of interdisciplinary study of the virtues. For example, the Arete Initiative at the University of Chicago (http://scienceofvirtues.org/) and the John Templeton Foundation offer grants to pursue interdisciplinary research on "the roots of good character in human nature" from a scientific, philosophical, and religious point of view (http://www.templeton.org/what-we-fund/core-funding-areas). See also the VIA Institute on Character, whose mission is "to advance both the science and the practice of character." (https:// www.viacharacter.org/www/en-us/viainstitute/about.aspx). In the popular media, one can see articles on the "science of compassion" (http://www.nytimes.com/2012/07/15/opinion/sunday/the-science-of-compassion. html), the "science of honesty" (http://www.apa.org/news/press/releases/2012/08/lying-less.aspx), the "new science of gratitude" (Emmons, 2007), the science of generosity, loyalty, and so on.

2. Deontic notions - from the Greek term deon, which means "duty" - are primarily focused on the moral evaluation of actions. They concern what one ought morally to do, what one ought not morally to do, and what one is morally permitted to do. Aretaic notions - e.g. "admirable" and "excellent"—have to do with the evaluation of persons and their moral characters. A moral theory counts as a form of virtue ethics, as I explain below, if and only if it treats aretaic notions as primary and deontic notions as either derivative (e.g. Wallace, 1978) or dispensable (e.g. Solomon, 1988).

3. I am grateful to an anonymous reviewer for pressing me to make a clear statement of my contributions to the fields of business ethics and psychology.

4. It is often said that virtue ethics is more about how to live than about what to do, but the distinction implies that living does not entail doing anything, a view that, I believe, most virtue ethicists would oppose. For the view that denies the status of virtue ethics as a third major position alongside Utilitarian and Kantian ethics see Nussbaum (1999).

5. Consequentialist and deontological theories are concerned with virtue but in terms of their traditional framework. Interest in Kant's virtue theory has redirected philosophers' attention to Kant's long neglected Doctrine of Virtue (Louden, 1986; O'Neill, 1996; Dierksmeier, 2013). Utilitarians also develop consequentialist virtue theories (Sigdwick, 1981; Hooker 2000, Driver, 2001). That explains why "virtue ethics"- as a theory in which the basic ethical judgments are judgments about character-is distinguished from "virtue theory," which designates an alternative account of virtue within one of the other two mainstream approaches. Under the umbrella term of virtue theory there is, then, room for virtue consequentialisms and deontological theories of virtue.

6. Aristotle claims that virtue is extensionally equivalent to phronesis, a form of intelligence, based on long experience, which enables the agent to navigate among various kinds of considerations in favor of or against certain actions. A virtuous person has to deal with these competing considerations in deliberating: one thing that makes ethics difficult is that one has to think about justice, rights, consequences, intuitions, etc. without having any algorithm for adjudicating among them.

7. As Bernard Williams puts it, "All that consequentialism is interested in is the idea of these doings being consequences of what I do" (1973: 245).

8. McLaughlin (2014) defines supervenience as follows: "A set of properties $A$ supervenes upon another set $B$ just in case no two things can differ with respect to $A$-properties without also differing with respect to their $B$-properties. In slogan form, 'there cannot be an $A$-difference without a $B$-difference.'” Davidson famously argued that mental characteristics are supervenient on physical characteristics where supervenience is taken to mean that "there cannot be two events exactly alike in all physical respects but differing in some mental respects, or that an object cannot alter in some mental respects without altering in some physical respects" (1970: 214).

9. Virtue has, I submit, what Owen (1960) labels as "focal meaning" (pros hen legomenon), that is, we can speak of a virtuous action, or principle, or community, but our meaning in each of those cases is somehow related to the notion of a virtuous person. In EN 1096b23-29, Aristotle states the focal meaning condition while discussing the senses in which different things are called good. See also EE 1236 a15-2 for an example of focal meaning ambiguity regarding what the term "friendship" has in common with "medical". According to Ferejohn (1980), what qualifies a term as having focal meaning is that even though it has a plurality of logoi with distinct significations, at the same time all of these signifiers point towards one single thing. I thank an anonymous reviewer for pressing this point. 
10. The concept of "virtuousness" in the POS literature is a bit obscure: "the ideal state of excellence in human or organizational character" (Bright et al, 2006: 251), "a constellation of virtues in the aggregate" (Cameron, 2011: 27), etc. The dictionary entry is more precise: virtuousness is "conduct that conforms to an accepted standard of right and wrong" (http://www.merriam-webster.com/thesaurus/virtuousness). An anonymous reviewer rightly observes that "virtuousness" in the POS tradition is mainly an organizational rather than an individual-level quality. The contention that collective entities such as business firms can develop the virtues is a controversial issue that I cannot examine here but have discussed elsewhere (e.g. Alzola, forthcoming).

11. I argue that character comprises higher-order desires and values, beliefs, framing capacities, emotions, and enduring patterns of behavior that have any bearing on moral matters (Alzola, 2012).

12. Aristotle, DA 427b8-428a4; EN 1114a32-b3; 1141b12-14; 1143b9-15; 1147a18-35.

13. Aristotle, EN 1105b25-26; 1111b1-5, 1115a8-16, 1125b26-1126a30; Rhet. 1378a24-28, 1379b3132, 1382b33-35.

14. Aristotle, EN 1104b13-16, 1139b1-5, 1145b915, 1146b10-17, 1150a2-8; Rhet. 1368b12-25, 1369a1-4

15. Aristotle, EN 1103b30, 1104b1-5, 1105b10-19, 1106b32, 1111b5-6, 1140b6-7, 1150b1-7, 1152a8, 1099a32-1099b6, 1178b6-7, 1179a4-10. See also Cooper (1985).

16. Aristotle, EN 1140b8-12; 1119b29-1120a5, 1128a35-1128b2, 1141a10-18. See also Foot (1981) and Williams (1985).

17. Aristotle, EN 1095b33, 1113a2-12, 1115b10-20, 1116a22-29, 1139a21-b5. See also Audi (1997), Davidson (2001), and Hartman (2013).

18. Aristotle, EN 1101b14, 1103a9-11, 1106a2, 1106b28-31, 1108a15-17, 1109a30, 1127b8, 1145b9-11, 1146a20-23, 1159a23-27.

19. An anonymous reviewer rightly suggests that we succeed in describing and explaining the man's action only if we are communicating with someone with whom we share some views about vice and virtue. If I say "he rescued the child because Poseidon did not wish to take him to his bosom," you will probably not feel enlightened. Aristotle's view of the explanation of behavior-and of much else-is irreducibly teleological, as that of some Enlightenment figures is not.

20. Notice that I write "strategies" rather than "conceptions of virtue," as I shall argue below that these are not simply contestable conceptions of the same concept. On the distinction between concepts and conceptions, see Rawls (1971).

21. There is a link between the philosophical debate over the normative priority of character and the methodological polemic over the reduction of virtue to actions. In Section Five, I shall argue that we cannot reduce virtue to behavior (the second polemic) if we take character and virtue to have normative priority (the first polemic) because a virtuous action is defined as what a person of good character would do under the circumstances. Hence, taking character seriously entails, I submit, a commitment to a different methodological approach to identifying and observing virtue. We need to study first the virtuous person rather than how his or her actions are in conformity with certain principles. See Sections 1.2. and 4. I am indebted to Associate Editor Ken Goodpaster for pressing this point.

22. Doris' own formulation is: "Character and personality traits are reliably manifested in trait-relevant behavior across a diversity of trait-relevant eliciting conditions that may vary widely in their conduciveness to the manifestation of the trait in question" (2002: 22).

23. Whether that applies to explaining performance (or non-performance) of a single action on each occasion is something contested in the reductive approach. While Azjen (2005: 72) argues that psychologists are not historians, in the sense that "they are rarely interested in an individual's action on any particular occasion," Doris claims that we want "to predict and explain not only general trends but also particular behaviors... it is not the broad behavioral trend but the particular behavior that is of central interest" (2002: 74).

24. See Sellars (1997) for an attempt to make psychological states and events as postulates of a theory that explains behavior. Such a view may not be reductive, even though one could say that he defines these states and events in behavioral terms in some sense. The psychological states and events are causes of behavior but in a completely different sense than the psychological theories described in this section.

25. The way the psychologist identifies character traits is through a process of checking their cultural validity and reliability (Reimer et al., 2009; Walker \& Pitts, 1998). The process begins by asking people to define the qualities of character of a person. Then, data reduction techniques are used to establish what the main characteristics are. Once a trait has been identified, the next step is the development of a 
measure, which includes items that describe characteristics of the trait (McCrae and Costa, 1995). Next, the measure is pilot tested and analyzed with factor analysis. Finally, the reliability and validity of the measure is assessed (Aquino and Reed 2002).

26. The authors make clear that these criteria are neither necessary nor sufficient conditions for character strengths but rather pertinent features that synthesize a "family resemblance" (Peterson and Seligman, 2004: 17).

27. Peterson and Seligman call them "signature strengths" and argue that they entail, among other things, "a feeling of inevitability in using the strength, as if one cannot be stopped or dissuaded from its display" (2004: 18).

28. On the unity of virtue thesis, see footnote 37 below.

29. Consider knowledge that $\mathrm{p}$ : it is psychologically indistinguishable from belief that $\mathrm{p}$ on the basis of good reasons; what makes it different is that $\mathrm{p}$ is the case. I thank Ed Hartman for the example of the mugger.

30. With "if possible" I mean something like Peter Singer's principle: "if it is in your power to prevent something bad from happening, without thereby sacrificing anything of comparable moral importance, you ought, morally, to do it" (Singer, 1972: 232).

31. A person $\mathrm{P}$ might believe that action $\mathrm{M}$ would lead to $\mathrm{T}$ but does not perform action $\mathrm{M}$ because $\mathrm{P}$ does not want T. Or maybe P wants T but does not believe that doing $\mathrm{M}$ will bring it about. We could get additional evidence by asking $\mathrm{P}$, by asking his peers, or by looking at his further actions. P might or might not embrace $\mathrm{T}$ if it happens some other way. Hence, it is not trivial to say that $\mathrm{P}$ did $\mathrm{M}$ because he wanted $\mathrm{T}$ and believed that $\mathrm{M}$ would bring $\mathrm{T}$ about. Yet, on the reductive account of virtues, the statement that a desire caused some behavior is not very informative, since a desire to do $\mathrm{M}$ is just a disposition to do $\mathrm{M}$. And, again, a reductive analysis of this sort has no theory to explain P's desire to do M coupled with his not doing M. I thank Ed Hartman for pressing me on this point.

32. The objector may reply that personality psychologists are happy to attribute personality traits on the basis of high scores in personality tests, even if the person has never behaved in such a manner. In response, one may argue that personality tests are used to construct rather than discover the trait being measured, in the sense that a person's degree of, say, conscientiousness, comes to exist after a test and only as a result of such a test (Hanson 1993). Even if personality psychologists can successfully meet that objection, I hope I have made the case for the claim that any measure of virtue should be able to capture the four dimensions of virtue described above. Hence, it is hard to see how one can attribute virtue solely on the basis of a bunch of personality tests.

33. Elsewhere I have argued that it is not possible, because we need to know more about the person's moral life, inside and outside the context of his or her choice (Alzola, 2008). We need to know more about the whole course of the person's life.

34. The non-reductive account is, as a helpful anonymous reviewer has suggested, a comprehensive account of virtue.

35. I am trying to avoid reductive virtue while maintaining that virtues do affect our behavior. I am just making the modest claim that virtues, which often appear embedded in the first premises of the practical syllogisms that give an account of our thought and action, typically cause the agent to act in a certain way. They do not always, but it is puzzling when they do not. So how can there be weakness of the will? One way it can happen is that we are motivated by something other than the virtue that appears in the first premise of the syllogism, and that might be because we are framing the action wrong in the second premise. So instead of thinking "One should eat nutritious food and this dry food is nutritious" and then eating the granola, I think: "One should eat delicious food and this donut is delicious" and then eat the donut. I have framed eating the donut as eating something delicious instead of framing it as eating something fattening and not nutritious. Aristotle's discussion of weakness of the will and of all associated topics is surely about motivation and action. I thank an anonymous reviewer for pressing this point.

36. Aristotle has listed at least seven ways in which even the fully virtuous person may act occasionally wrongly (from succumbing to overwhelming pressures, to acting temporarily out of character, etc.), while still remaining virtuous overall (Curzer, 2005).

37. According to this traditional thesis, anyone who has one of the virtues must have all of them because there is really no set of distinct and separate good character traits but rather, at the bottom, only a single, unitary virtue. 
38. The thesis of the "modularity of virtue" was first introduced by Owen Flanagan (1991), who argued that the virtues have different emotional bases, domains, and learning histories. The virtues, according to Flanagan, possess characteristics of other skills that have been modeled modularly, such as language and the basic emotions. I have discussed the modularity of virtue elsewhere (see Alzola, 2012).

39. Other suggested techniques include recording the physiological responses of the subjectse.g. heart rate, eye-tracking, pupillary response, skin response-to measure cognitive, affective, and behavioral responses to situations that call for the virtues (Decety, Michalska, \& Kinzler, 2012). I thank an anonymous reviewer for urging this point on me. And I am indebted to Danielle Warren for guiding me to the literature on experience sampling and diary methods and other tools for real-time measurement in natural settings.

40. Attractive as it is, we should be cautious about the use of these techniques. Can we determine a person's character by collecting his or her recorded responses to virtue-relevant stimuli? Assuming that the experimenter and maybe also the subject know in advance what is virtue-relevant, this method would at best offer a rather small amount of evidence about one's character, and we probably cannot accurately characterize a certain response without already knowing a fair amount about the agent's character. Suppose the agent records shuddering when seeing Jones beating Smith. Is the shudder a shudder of fear or a shudder of moral indignation? We cannot answer that question without knowing something about the agent's character because, first, any assessment of character, as to whether it is virtuous or not, presupposes some moral point of view, and second, because we cannot understand what it means to act virtuously independently from the study of the virtuous person.

41. It is surprising that positive psychologists have listed gratitude under the strength of "transcendence" - which is defined as the strength that forges connections to the larger universe and provide meaning - rather than under the strength of humanity ("Interpersonal strength that involves tending and befriending others").

42. One might give a similar account of penitence, repentance, and similar virtues: one cannot truly apologize insincerely, etc. See Roberts (1995), Gibson et. al. (1999), and Exline et. al. (2003).

43. An anonymous reviewer rightly points out that Aristotle did not list gratitude as a virtue since it is inconsistent with the Aristotelian virtue of magnanimity. The Stagirite thinks that a grateful attitude is somehow demeaning, putting the agent in acceptance of the debtor position, that is, a position that a noble man would never accept. Similarly, Epicurus regarded gratitude almost as a vice, as it entails a susceptibility to fear (Roberts, 2004). Still, Aristotelian scholars, from Hursthouse (1999) to Hartman (2006), take gratitude to be a virtue in the way discussed in this paper, and Kristjánsson (2014) has recently made a strong case for an Aristotelian virtue of gratitude.

44. Methodologically, the non-reductive account raises a problem of circularity: virtue is supposed to be habitually manifested in the agent's behavior. But, we cannot assess the agent's action without full information about the agent's state of character because the action is not virtuous unless performed by a virtuous agent. On the other hand, we cannot assess the agent's character without considering his or her actions, reactions, and motivations. There are a number of strategies to effectively rebut the objection of circularity but I cannot discuss them here. See Hursthouse (1999).

\section{REFERENCES}

Adams, R. M. 2006. A theory of virtue: Excellence in being for the good. Oxford: Oxford University Press.

Ajzen, I. 2005. Attitudes, personality, and behavior. New York: McGraw-Hill International.

Algoe, S. B., \& Haidt, J. 2009. Witnessing excellence in action: The 'other-praising' emotions of elevation, gratitude, and admiration. The Journal of Positive Psychology, 4(2): 105-127.

Algoe, S. B., Haidt, J., \& Gable, S. L. 2008. Beyond reciprocity: gratitude and relationships in everyday life. Emotion, 8(3): 425-429.

Allport, G.W. 1937. Personality: A psychological interpretation. New York: Henry Holt and Company.

Alston, W.P. 1975. Traits, consistency and conceptual alternatives for personality theory. Journal for a Theory of Social Behavior, 5: 17-48. 
Alzola, M. 2008. Character and environment: The status of virtues in organizations. Journal of Business Ethics, 78: 343-357.

. 2011. The reconciliation project: Separation and integration in business ethics research. Journal of Business Ethics, 99(1): 19-36. . 2012. The possibility of virtue. Business Ethics Quarterly, 22: 377-404.

. (forthcoming). Corporate roles and virtues. In Sison, A. J. (Ed.), Handbook of virtue ethics in business and management. Springer Reference.

. (forthcoming). Character-based business ethics. In Snow, Nancy (Ed.), The Oxford handbook of virtue. New York: Oxford University Press.

Annas, J. 2011. Intelligent virtue. New York and Oxford: Oxford University Press.

Aquino, K., \& Reed, A II. 2002. The self-importance of moral identity. Journal of Personality and Social Psychology, 83(6): 1423-.

Aristotle. 1984. De anima. (DA) In Barnes, J. (Ed.), The complete works of Aristotle volume 1. Princeton, NJ: Princeton University Press.

. 1999. Ethica nicomachea. (EN) Translated by Irwin, T.H., $2^{\text {nd }}$ Edition. Indianapolis: Hackett Publishing Co.

Armstrong, D. M. 1969. Dispositions are causes. Analysis, 30: 23-26.

Armstrong, D. M., Martin, C. B. \& Place, U. T. 1996. Dispositions: A debate. London: Routledge.

Arnold, D. G., Beauchamp, T. L., \& Bowie, N. E. (Eds.). 2012. Ethical theory and business. Upper Saddle River: Prentice Hall.

Audi, R. 1995. Acting from virtue. Mind, 104(415): 449-471.

. 1997. Moral knowledge and ethical character. New York: Oxford University Press.

2009. The good in the right: A theory of intuition and intrinsic value. Princeton, NJ: Princeton University Press.

Barrick, M. R., \& Mount, M. K. 1991. The big five personality dimensions and job performance: A meta-analysis. Personnel Psychology, 44: 1-26.

Bartlett, M. Y., Condon, P., Cruz, J., Baumann, J., \& Desteno, D. 2012. Gratitude: Prompting behaviours that build relationships. Cognition \& Emotion, 26(1): 2-13.

Beauchamp, T. L., \& Childress, J. F. 1983. Principles of biomedical ethics. Oxford: Oxford University Press.

Becker, L. C. 1986. Reciprocity. New York: Routledge \& Kegan.

Berger, F. R. 1975. Gratitude. Ethics, 85: 298-309.

Bird, A., 1998. Dispositions and antidotes. The Philosophical Quarterly, 48: 227-234.

Bird, G.N. 1954. Mr. Hampshire on dispositions. Analysis, 14(4): 100-102.

Boatright, J. R. 2012. Ethics and the conduct of business. Upper Saddle River, NJ: Prentice-Hall.

Brandt, R.B. 1970. Traits of character: A conceptual analysis. American Philosophical Quarterly, 7: 23-37.

. 1988. The structure of virtue. Midwest Studies in Philosophy, 13(1): 64-82.

Bright, D., Cameron, K. \& Caza, A. 2006. The amplifying and buffering effects of virtuousness in downsized organizations. Journal of Business Ethics, 64: 249-269.

Bright, D. S., Stansbury, J., Alzola, M., \& Stavros, J. M. 2011. Virtue ethics in positive organizational scholarship: An integrative perspective. Canadian Journal of Administrative Sciences, 28(3): 231-243.

Bright, D. S., Winn, B. A., \& Kanov, J. 2014. Reconsidering virtue: Differences of perspective in virtue ethics and the positive social sciences. Journal of Business Ethics, 119(4): 445-460. 
Bruni, L., \& Sugden, R. 2013. Reclaiming virtue ethics for economics. The Journal of Economic Perspectives, 27(4): 141-163.

Cameron, K. and Winn, B. 2011. Virtuousness in organizations. In Cameron, K. S. \& Spreitzer, G. M. (Eds.), The Oxford handbook of positive organizational scholarship: 231-243. New York, NY: Oxford University Press.

Cameron, K. S. 2013. Advances in positive organizational scholarship. In Bakker, A. B. (Ed.), Advances in positive organizational psychology (Advances in positive organizational psychology, volume 1): 23-44. Emerald Group Publishing Limited.

Cameron, K. S., \& Spreitzer, G. M. (Eds.). 2011. The Oxford handbook of positive organizational scholarship. New York: Oxford University Press.

Cameron, K., Dutton, J., \& Quinn, R. E. (Eds.). 2003. Positive organizational scholarship. San Francisco: Berrett-Koehler.

Card, C. 1988. Gratitude and obligation. American Philosophical Quarterly, 25: 115-127.

Carr, A. 2011. Positive psychology. New York: Routledge.

Carr, D. 1988. The cardinal virtues and plato's moral psychology. The Philosophical Quarterly, 38: 151.

2013. Varieties of gratitude. The Journal of Value Inquiry, 47: 17-28.

Cattell, R. B. 1943. The description of personality: I. Foundations of trait measurement. Psychological Review, 50: 559-594.

Cattell, R. B., \& Dreger, R. M . (Eds.). 1978. Handbook of modern personality theory. New York: Wiley.

Chatman, J., \& Barsade, S. 1995. Personality, culture, and cooperation: Evidence from a business situation. Administrative Science Quarterly, 40: 423-443.

Cheng, P.W. 1997. From covariation to causation: A causal power theory. Psychological Review, 104: 367-405.

Cooper, J. M. 1985. Aristotle on the goods of fortune. The Philosophical Review, 94(2): 173-196.

1998. The unity of virtue. Social Philosophy and Policy, 15(1): 233-274. . 1999. Reason and emotion: Essays on ancient moral psychology and ethical theory. Princeton, NJ: Princeton University Press.

Costa, P. T, Jr., \& McCrae, R. R. 1985. The NEO personality inventory manual. Odessa, FL: Psychological Assessment Resources.

Crisp, R. 1996. How should one live? Essays on the virtues. Oxford: Oxford University Press.

Cross, T., 2005. What is a disposition? Synthese, 144: 321-341.

Curzer, H. J. 1990. A great philosopher's not so great account of great virtue: Aristotle's treatment of greatness of soul. Canadian Journal of Philosophy, 20(4): 517-537. 2005. How good people do bad things: Aristotle on the misdeeds of the virtuous. Oxford Studies in Ancient Philosophy, 28(1): 233-256.

Darley, J. M., \& Batson, C. D. 1973. From Jerusalem to Jericho: A study of situational and dispositional variables in helping behavior. Journal of Personality and Social Psychology, 27: 100-108.

Darley, J. M., \& Latane, B. 1968. Bystander intervention in emergencies: Diffusion of responsibility. Journal of Personality and Social Psychology, 8: 377-383.

Davidson, D. 2001. Essays on actions and events. $2^{\text {nd }}$ Edition. Oxford: Clarendon Press.

Decety, J., Michalska, K. J., \& Kinzler, K. D. 2012. The contribution of emotion and cognition to moral sensitivity: A neurodevelopmental study. Cerebral Cortex, 22(1): 209-220.

Dent, N. J. H. 1975. Virtues and actions. The Philosophical Quarterly, 25: 327-328. 
Dewey, J. 1922. Human nature and conduct. New York: New York Random House. Dierksmeier, C. 2013. Kant on virtue. Journal of Business Ethics, 113(4): 597-609.

Donaldson, T., \& Werhane, P. 2008. Ethical issues in business: A philosophical approach. $\boldsymbol{8}^{\text {th }}$ Edition. Upper Saddle River, NJ: Prentice-Hall.

Doris, J. M. 2002. Lack of character: personality and moral behavior. New York: Cambridge University Press. 2009. Ethics without persons. Unpublished paper (courtesy of John Doris).

Doris, J. M., \& Stich, S. P. 2005. As a matter of fact: Empirical perspectives on ethics. In Jackson, F. \& Smith, M. (Eds.), The Oxford handbook of contemporary philosophy. Oxford: Oxford University Press.

Driver, J. 2001. Uneasy virtue. Cambridge: Cambridge University Press.

Dutton, J. E., Worline, M. C., Frost, P. J., \& Lilius, J. M. 2006. Explaining compassion organizing. Administrative Science Quarterly, 51: 59-96.

Dutton, J. E., Glynn, M., \& Spreitzer, G. M. 2006. Positive organizational scholarship. In Greenhaus, J. \& Callanan, G. (Eds.), Encyclopedia of career development: 641644. California: Sage Publications.

Emmons, R. A. 2003. Acts of gratitude in organizations. In Cameron, K. S., Dutton, J. E., and Quinn, R. E. (Eds.), Positive organizational scholarship. San Francisco: BerrettKoehler Publishers.

. 2007. Thanks!: How the new science of gratitude can make you happier. Boston: Houghton Mifflin Harcourt.

Emmons, R. A., \& McCullough, M. E. 2003. Counting blessings versus burdens: An experimental investigation of gratitude and subjective well-being in daily life. Journal of Personality and Social Psychology, 84(2): 377-389.

Emmons, R. A., \& McCullough, M. E. (Eds.). 2004. The psychology of gratitude. Oxford: Oxford University Press.

Epstein, S. 1984. The stability of behavior across time and situations. In Zucker, R. A., Aronoff, J., \& Rabin, A. I. (Eds.), Personality and the prediction of behavior: 209-268. Orlando, FL: Academic Press.

Exline, J. J., Worthington, E. L., Hill, P., \& McCullough, M. E. 2003. Forgiveness and justice: A research agenda for social and personality psychology. Personality and Social Psychology Review, 7(4): 337-348.

Eysenck, H. J. 1991. Dimensions of personality: 16, 5, or 3? Criteria for a taxometric paradigm. Personality and Individual Differences, 12: 773-790.

Fara, M. 2005. Dispositions and habituals. Nô̂s, 39: 43-82.

Feinberg, J. 1970. The nature and value of rights. Journal of Value Inquiry, 4: 243-260.

Ferejohn, M. T. 1980. Aristotle on focal meaning and the unity of science. Phronesis, 25(2): 117-128.

Fitzgerald, P. 1998. Gratitude and justice. Ethics, 109: 119-143.

Flanagan, O. J. 1991. Varieties of moral personality: Ethics and psychological realism. Cambridge, MA: Harvard University Press.

Foot, P. 1981. Virtues and vices and other essays in moral philosophy. Oxford: Basil Blackwell. Frankena, W. M. 1973. Ethics. ${ }^{\text {nd }}$ Edition. Englewood Cliffs, N.J.: Prentice Hall.

Funder, D. C. 1997. The personality puzzle. 1st Edition. New York: W.W. Norton \& Co.

Gert, B. 2005. Morality: Its nature and justification. Revised Edition. New York: Oxford University Press.

Gewirth, A. 1978. Reason and morality. Chicago: University of Chicago Press.

Gibson, K., Bottom, W., \& Murnighan, J. K. 1999. Once bitten: Defection and reconciliation in a cooperative enterprise. Business Ethics Quarterly, 9(1): 69-85. 
Goodwin, G. P., Piazza, J., \& Rozin, P. 2014. Moral character predominates in person perception and evaluation. Journal of Personality and Social Psychology, 106(1): $148-168$.

Gunthert, K. C., \& Wenze, S. J. 2012. Daily diary methods. In Mehl, M. R., \& Conner, T. S. (Eds.), Handbook of research methods for studying daily life: 144-159. New York: Guilford Press.

Haidt, J. 2006. The happiness hypothesis: Finding modern truth in ancient wisdom. New York: Basic Books.

Hampshire, S. 1953. Dispositions. Analysis, 14: 5-11.

Hanson, F. A. 1993. Testing testing: Social consequences of the examined life. Berkeley: University of California Press.

Harman, G. 1999. Moral philosophy meets social psychology: Virtue ethics and the fundamental attribution error. Proceedings of the Aristotelian Society, 99: 315-31.

. 2000. The nonexistence of character traits. Proceedings of the Aristotelian Society, 100: 223-226.

. 2001. Virtue ethics without character traits. In Byrne, A., Stalnaker, R., \& Wedgwood, R. (Eds.), Fact and value: 117-127. Cambridge: The MIT Press. . 2003. No character or personality. Business Ethics Quarterly, 13(1): 87-94.

Hartman, E. M. 1998. The role of character in business ethics. Business Ethics Quarterly, 8: $547-559$.

- 2013. Virtue in business: Conversations with Aristotle. New York: Cambridge University Press.

Hartshorne, H., \& May, M. A. 1928. Studies in the nature of character: Vol. I.studies in deceit. New York: Mac-Millan.

Hooker, B. 2000. Ideal code, real world. Oxford: Oxford University Press.

Hursthouse, R. 1999. On virtue ethics. Oxford: Oxford University Press.

Irwin, T. H. 1988. Disunity in the Aristotelian Virtues. Oxford Studies in Ancient Philosophy, Supplementary Volume: 61-78.

Isen, A. M., \& Levin, P. F. 1972. Effect of feeling good on helping: Cookies and kindness. Journal of Personality and Social Psychology, 21: 384-388.

Kant, I. 1996. Groundwork of the metaphysics of morals. In Gregor, M. J. (Trans and Ed.), Practical philosophy: The Cambridge edition of the works of Immanuel Kant: Cambridge: Cambridge University Press. pp. 37-108.

Koehn, D. 1998. Virtue ethics, the firm, and moral psychology. Business Ethics Quarterly, 8: 497-513.

Korsgaard, C. M. 1996. From duty and for the sake of the noble: Kant and Aristotle on morally good action. In Engstrom, S. \& Whiting, J. (Eds.), Aristotle, Kant, and the stoics: Rethinking happiness and duty: New York: Cambridge University Press. pp. 203-236.

Kristjánsson, K. 2013. Virtues and vices in positive psychology. New York: Cambridge University Press.

. 2014. An Aristotelian virtue of gratitude. Topoi, 1-13. 10.1007/s11245-013-9213-8.

Kupperman, J. J. 1991. Character. New York: Oxford University Press.

Lambert, N. M., Graham, S. M., \& Fincham, F. D. 2009. A prototype analysis of gratitude: Varieties of gratitude experiences. Personality and Social Psychology Bulletin, 35(9): 1193-1207.

Latané, B., \& Rodin, J. 1969. A lady in distress: Inhibiting effects of friends and strangers on bystander intervention. Journal of Experimental Social Psychology, 37: 822-832.

Lopez, S. J., \& Snyder, C. R. (Eds.). 2011. The Oxford handbook of positive psychology.

Oxford: Oxford University Press. 
Louden, R. B. 1986. Kant's virtue ethics. Philosophy, 61(238): 473-489.

MacIntyre, A. 1998. What can moral philosophers learn from the study of the brain? Philosophy and Phenomenological Research, 58(4): 865-9.

Martin, M. W. 2006. From morality to mental health: virtue and vice in a therapeutic culture. Oxford: Oxford University Press.

McAleer, S. 2012. Propositional gratitude. American Philosophical Quarterly, 49: 55-66.

McCrae, R. R., \& Costa, P. T, Jr. 1995. Trait explanations in personality psychology. European Journal of Personality, 9: 231-252.

McCloskey, D. N. 2006. The bourgeois virtues: Ethics for an age of commerce. Chicago: University of Chicago Press.

McCullough, M. E., Emmons, R. A., \& Tsang, J. A. 2002. The grateful disposition: A conceptual and empirical topography. Journal of Personality and Social Psychology, 82(1): 112-127.

McDowell, J. 1998. Non-cognitivism and rule-following. In Mind, Value, and Reality: 198-220. Cambridge, MA: Harvard University Press.

McKitrick, J., 2005. Are dispositions causally relevant? Synthese, 144: 357-371.

McLaughlin, B., \& Bennett, K. 2014. "Supervenience", The Stanford Encyclopedia of Philosophy (Spring 2014 Edition), Zalta, Edward N. (Ed.), available at http://plato. stanford.edu/archives/spr2014/entries/supervenience.

Mehl, M. R., \& Pennebaker, J. W. 2003. The sounds of social life: a psychometric analysis of students' daily social environments and natural conversations. Journal of personality and social psychology, 84(4): 857-870.

Mehl, M. R., \& Conner, T. S. 2012. Handbook of research methods for studying daily life. New York: Guilford Press.

Milgram, S. 1974. Obedience to authority. Harper and Row: New York.

Moberg, D. J. 1997. On employee vice. Business Ethics Quarterly, 7: 41-60.

— 1999. The big five and organizational virtue. Business Ethics Quarterly, 9: 245-272.

Moore, G. 2005. Corporate character: Modern virtue ethics and the virtuous corporation. Business Ethics Quarterly, 15(4): 659-685.

Narvaez, D. 2008. Human flourishing and moral development: Cognitive and neurobiological perspectives of virtue development. In Nucci, L. \& Narvaez, D. (Eds.), Handbook of Moral and Character Education: 310-327. New York: Routledge.

Nussbaum, M. 1988. Non-relative virtues: An Aristotelian approach. In French, P. A., Uehling, T. E. Jr., \& Wettstein, H. K. (Eds.), Ethical Theory: Character and Virtue Midwest Studies in Philosophy, 13: 32-53. Notre Dame, IN: University of Notre Dame Press.

Nussbaum, M. C. 1999. Virtue ethics: A misleading category? The Journal of Ethics, 3(3): 163-201.

O'Neill, O. 1996. Kant's virtues. In Crisp, R. (Ed.), How should one live? Essays on the virtues: 77-97. Oxford: Oxford University Press.

Owen, G. E. L. 1979. Logic and metaphysics in some earlier works of Aristotle. Reprinted in Barnes, J., Schofield, M., \& Sorabji, R. R. K. (Eds.), Articles on Aristotle Vol. 3. Metaphysics: 13-32. London: Duckworth.

Pervin, L. A., Cervone, D., \& John, O. P. 2005. Personality theory and research. 9 $^{\text {th }}$ Edition. Hoboken, NJ: John Wiley \& Sons, Inc.

Peterson, C., \& Seligman, M. E. P. 2004. Character strengths and virtues: A classification and handbook. New York: Oxford University Press/Washington, DC: American Psychological Association. 
Putnam, H. 2002. The collapse of the fact/value dichotomy and other essays. Cambridge, MA: Harvard University Press.

Rawls, J. 1971. A theory of justice. Cambridge, MA: Harvard University Press.

Reimer, K. S., Goudelock, DeWitt, B. M., \& Walker, L. J. 2009. Developing conceptions of moral maturity: Traits and identity in adolescent personality. The Journal of Positive Psychology, 4(5): 372-388.

Richardson, F. 2003. Virtue ethics, dialogue, and reverence. American Behavioral Scientist, 47: 442-458.

Roberts, R. C. 1995. Forgivingness. American Philosophical Quarterly, 32(4): 289-306. - 2004. The blessings of gratitude. In Emmons, R. A. \& McCullough, M. E. (Eds.), The psychology of gratitude: 58-78. Oxford: Oxford University Press.

Ross, L. \& Nisbett, R. E. 1991. The person and the situation: perspectives of social psychology. Temple University Press: Philadelphia.

Ross, W. D. 2002. The right and the good. Oxford: Oxford University Press.

Ryle, G., 1949. The concept of mind. London: Hutchinson \& Co.

Sabini, J., \& Silver, M. 2005. Lack of character? Situationism critiqued. Ethics, 115: 535-62.

Seligman, M. E. P. 2002. Authentic happiness. New York: Free Press.

Seligman, M., \& Csikszentmihalyi, M. 2000. Positive psychology: An Introduction. American Psychologist, 55: 5-14.

Seligman, M. E. P. 2011. Flourish: A new understanding of happiness and well-being and how to achieve them. Boston: Nicholas Brealey Publishing.

Sellars, W. 1997. Empiricism and the philosophy of mind. Cambridge, MA: Harvard University Press.

Sherman, N. 1997. Making a necessity of virtue: Aristotle and Kant on virtue. Cambridge, MA: Cambridge University Press.

Sidgwick, H. 1907/1981. The methods of ethics. Indianapolis: Hackett Publishing Company. Singer, P. 1972. Famine, affluence, and morality. Philosophy \& Public Affairs 1(1): 229-243.

Slote, M. A. 1983. Goods and virtues. Oxford: Clarendon Press.

Smart, J. J. C., \& Williams, B. 1973. Utilitarianism: For and against. Cambridge, MA: Cambridge University Press.

Snow, N. 2010. Virtue as social intelligence: An empirically grounded theory. New York: Routledge.

. 2014. Virtue intelligence. Unpublished manuscript. Department of Philosophy, Marquette University (Courtesy of Nancy Snow).

Solomon, R. C. 1997. Ethics and excellence. New York: Oxford University Press.

- 2005. What's character got to do with it?. Philosophy and Phenomenological Research, 71(3): 648-655.

Solomon, D. 1988. Internal objections to virtue ethics. Midwest Studies in Philosophy, 13(1): 428-441.

Sonnentag, T. L., \& McDaniel, B. L. 2013. Doing the right thing in the face of social pressure: Moral rebels and their role models have heightened levels of moral trait integration. Self and Identity, 12(4): 432-446.

Staw, B. M., Bell, N. \& Clausen, J. 1986. The dispositional approach to job attitudes: A lifetime longitudinal test. Administrative Science Quarterly, 31: 56-77.

Sugden, R. 2015. Team reasoning and intentional cooperation for mutual benefit. Journal of Social Ontology, 1(1): 143-166.

Swanton, C. 2001. A virtue ethical account of right action. Ethics, 112(1): 32-52.

Timpe, K., \& Boyd, C. A. (Eds.). 2014. Virtues and their vices. Clarendon: Oxford University Press. 
Treviño, L., \& Youngblood, S. 1990. Bad apples in bad barrels: A causal analysis of ethical decision-making behavior. Journal of Applied Psychology, 75(4): 378-385.

Trevino, L. K., \& Nelson, K. 2003. Managing business ethics; Straight talk about how to do it right. 3rd Edition. New York: Wiley.

Van Slyke, J. A., Peterson, G., Brown, W. S., Reimer, K. S., \& Spezio, M. L. (Eds.). 2012. Theology and the science of moral action: Virtue ethics, exemplarity, and cognitive neuroscience. New York: Routledge.

Velasquez, M. 2012. Business ethics, a teaching and learning classroom edition: Concepts and cases. Upper Saddle River: Prentice Hall.

Vianello, M., Galliani, E. M., \& Haidt, J. 2010. Elevation at work: The effects of leaders' moral excellence. The Journal of Positive Psychology, 5(5): 390-411.

Von Wright, G. H. 1963. The varieties of goodness. London: Routledge and Kegan.

Walker, A. D. M. 1988. Obligation and the argument from gratitude. Philosophy and Public Affairs, 17: 191-211.

Walker, L. J., \& Pitts, R. C. 1998. Naturalistic conceptions of moral maturity. Developmental Psychology, 34(3), 403.

Wallace, J. D. 1978. Virtues and vices. Ithaca, New York: Cornell University Press.

Watkins, P. C., Woodward, K., Stone, T., \& Kolts, R. L. 2003. Gratitude and happiness: Development of a measure of gratitude, and relationships with subjective well-being. Social Behavior and Personality: an international journal, 31(5): 431-451.

Weiss, R. 1985. The moral and social dimensions of gratitude. The Southern Journal of Philosophy, 23: 491-501.

Wellman, C. H. 1999. Gratitude as a virtue. Pacific Philosophical Quarterly, 80: 284-300.

Williams, B. 1985. Ethics and the limits of philosophy. Cambridge, MA: Harvard University Press.

- 2006. The primacy of dispositions. In Williams, B. (Ed.), Philosophy as a Humanistic Discipline: 67-75. Princeton: Princeton University Press.

Wood, A. M., Maltby, J., Stewart, N., \& Joseph, S. 2008. Conceptualizing gratitude and appreciation as a unitary personality trait. Personality and Individual Differences, 44(3): 621-632.

Woods, M. 1986. Intuition and perception in Aristotle's ethics. Oxford Studies in Ancient Philosophy, 4: 145-66

Worline, M. C., \& Quinn, R. W. 2003. Courageous principled action. In Cameron, K. S., Dutton, J. E., \& Quinn, R. E. (Eds.), Positive Organizational Scholarship. San Francisco: Berrett-Koehler.

Wright, T.A., \& Goodstein, J. 2007. Character is not "dead" in management research: A review of individual character and organizational-level virtue. Journal of Management, 33(6): 928-958.

Zagzebski, L. T. 1996. Virtues of the mind: An inquiry into the nature of virtue and the ethical foundations of knowledge. New York: Cambridge University Press. 